\title{
Government and business community attitudes towards cruise tourism development
}

\author{
Smiljana Pivčević ${ }^{A *}$, Ante MandićA, Niko Šalja ${ }^{B}$ \\ Received: September 02, 2018 | Revised: November 21, 2018 | Accepted: November 27, 2018 \\ DOI: $10.5937 / \mathrm{gp} 22-18750$
}

\begin{abstract}
This study analyses government and business community attitudes towards cruise tourism impacts and its future development. An empirical study was conducted in Dubrovnik on a sample of 105 leaders in tourism-related organisations developing, validating and using the the Cruise Tourism Impacts scale. Research findings reveal a moderately positive attitude towards the cruise tourism impacts and the desired shift in future development priorities. Promotion, revenues and employment generation are the most pronounced positive impacts and cruise tourism influence on land-based guests the most pronounced negative one. Only sex and workplace are found to be discriminators of cruise tourism impacts perceptions. Implications for destination management and suggestions for future studies are provided.
\end{abstract}

Keywords: cruise tourism impacts; government and business stakeholders; discriminating variables; Dubrovnik

\section{Introduction}

Cruise tourism is increasingly recognised as a successful and dynamic subsector of the global tourism industry, with the major cruise lines occupying the highest ranks of tourism and leisure sector's shareholder capital and annual profits (Weeden et al., 2011). In the attempt to embrace cruise industry's expansion, destinations need to manage the often-diverse needs of their communities while protecting the local environment and minimising any cruise tourism induced costs (Lester \& Weede, 2004; Shone et al., 2017). Stakeholders' perceptions of tourism development and its potential future directions are important in gaining or maintaining support for development decisions (Presenza et al., 2013). Namely, understanding stakeholders' perspective can facilitate policies, which minimise potential negative tourism impacts and maximise the benefits, thus leading to greater community support for tourism (Timur \& Getz, 2008). However, stakeholders' attitudes toward tourism development differ (Kuvan \& Akan, 2012; Alonso \& Alexander, 2017), over time even within initially homogenous groups (Ven, 2015). Surprisingly or not, most tourism and cruise tourism studies focus on residents' attitudes (Sharpley, 2014; Jordan \& Vogt, 2017; Del Chiappa et al., 2016; Brida et al., 2012; Woosnam et al., 2018; McCaughey et al., 2018; Jordan \& Vogt, 2017; Del Chiappa et al., 2018). Despite this, cruise tourism can still be considered a somehwat underinvestigated reserach area in tourism, i.e. further research is needed to enlighten and evaluate the objective (economic) and subjective (stakeholders perception) impacts that cruise visitors generate in destinations (Del Chiappa, 2018). To fill that gap, this study addresses the local government and the business community. Moreo-

\footnotetext{
A University of Split; Faculty of Economics, Business and Tourism; Department of Tourism and Economy, Cvite Fiskovića 5, 21000 Split, Croatia; smiljana.pivcevic@efst.hr; ante.mandic@efst.hr

B Niko Šalja, Šipčine 8, 20000 Dubrovnik, Croatia; info@dentistdubrovnik.com

* Corresponding author: Smiljana Pivčević; e-mail:smiljana.pivcevic@efst.hr; Tel: 0038521430669; Fax: 0038521430701
} 
ver, the authors propose Cruise Tourism Impact Scale (TCIS) and explore local government and business community attitudes towards (1) identified positive and negative cruise tourism impacts and (2) future cruise tourism development, in Dubrovnik, a renown Mediterranean cruise tourism destination.

\section{Literature review}

Harmonious interrelations between community, visitors and places they encounter, and supporting businesses is vital for successful tourism development (Sharpley, 2014). Thus, the importance of understanding stakeholders' perceptions and attitudes toward tourism development is widely acknowledged (Timur \& Getz, 2008; Del Chiappa, 2012; McCaughey et al., 2018) as well as the premise that tourism development needs to be planned and managed in line with stakeholders needs and attitudes (Sdrail et al., 2015; Ali et al., 2017).

Stakeholder can be defined as "any group or individual who can affect or is affected by the achievement of the organisation's objectives" (Freeman, 1984). Consequently, no wonder this conception has been widely accepted in tourism management literature as different stakeholders are involved in destination management, planning and marketing, while the issue of collaboration is seen as a crucial for destination competitiveness (D'Angella \& Go, 2009). In other words, tourism authorities need to consider all stakeholders involved in their unique business ecosystem to foster their cooperation for a successful destination development (Todd et al., 2017; Uran \& Zirdum, 2017). Furthermore, Social exchange theory, which is used to explain the perceptions of the economic, socio-cultural and environemental values and costs in the guest/host exchange (Brida et al., 2011; Petrić \& Pivčević, 2016) implies continous process of negotiation in which both groups, tourist and residents aim to optimise benefits (Sharpley, 2008). Moreover, tourism development implies exchange between money and territory (Bimonte \& Punzo, 2007), while the ratio of value/cost perceived by residents provides a strong indication of their attitudes towards tourism development and associated activities in their community (McCaughey et al., 2018). A so called „development dilemma" is in place (Tefler \& Sharpley, 2008), i.e. a trade-off between the tourism benefits and negative impacts. Thus, assessing the heterogeneous perceptions of stakeholders at different levels of tourism development (Lee \& Jan, 2019) and considering different types of niche tourism is crucial. Additionally, the relationship between the local community and tourism development can also be analysed from an economic perspective, i.e. behaviour of an economic agent is a matter of trade-offs between positive and negative externalities deriving from economic ac- tivities (Meleddu, 2012, as cited in Brida et al., 2012). The classification of cruise tourism stakeholders proposed by London and Lohmann (2014) is very useful when studying the individual group behaviour and attitudes. They identify four main groups of cruise tourism stakeholders, namely: (1) cruise industry, (2) gatekeeper stakeholders - regulatory officials, airlines and other long-haul transport providers who determine whether ships, passengers and crew visit a given cruise destination, (3) portside stakeholders - involved with ships and passengers within the area of port and cruise terminal and (4) shoreside stakeholders - broad group of stakeholders involved with passengers (and crew) on-shore, in the destination i.e. the community integrating government, the business community and residents. Furthermore, they stress the cooperation of all stakeholders to be the essential prerequisite of sustainable tourism development supporting the stance of other authors on the issue (Fredline \& Faulkner, 200o; Presenza et al., 2013). Consequently, unveiling tourism-related attitudes of diverse stakeholders can be seen as the first step in this vital process. However, this is not reflected in the research literature as all stakeholders are not studied with the same frequency. Moreover, studies focusing on residents prevail in general tourism (Nunkoo \& Gursoy, 2012; Sharpley, 2014; Lee \& Jan, 2019) and cruise tourism literature (Shone et al., 2017; Jordan \& Vogt, 2017; Woosnam et al., 2018; McCaughey et al., 2018; Jordan \& Vogt, 2017; Del Chiappa et al., 2018), while studies on other stakeholders are limited (Del Chiappa \& Abbate, 2013; Castillo-Manzano et al., 2014; Alonso \& Alexander, 2017). This is quite surprising knowing that research has revealed a divergence between diverse stakeholders' attitudes, e.g. perceived environmental and economic impacts (Kuvan \& Akan, 2012). Furthermore, according to Ven (2015), even stakeholders' groups with initially homogenous attitudes toward tourism development diverge over time. Thus, recently, researches call for studying attitudes of all tourism stakeholders especially in developed and maturing tourism destinations (McGahey, 2012 as cited in Ali et al., 2017; Castillo-Manzano et al. 2015). To fill this research gap, this study analyses the attitudes of local government and business community by introducing and validating the Cruise tourism impacts scale (CTIS). Additionally, the study addresses the attitudes regarding the impacts of cruise tourism on land-based tourism consid- 
ering this aspect has not been sufficiently addressed in previous studies, as well as the views about the fu- ture of cruise tourism development. The empirical research is carried out in Dubrovnik - Croatia.

\section{Study destination - the city of Dubrovnik}

The city of Dubrovnik is a prominent tourism centre situated on the southern Adriatic Sea coast in Croatia (Figure 1). Owing to its long and rich history, UNESCO listing, beautiful scenery and mild climate, it is one of the leading tourism destinations in the country, facing continuous visitor growth.

With population of 42,615 in the city area and approximately 1557 in the historical centre (Državni zavod za statistiku, 2011), the tourists per inhabitant ratio in the city area has risen from 30 in 2011 to 44 in $2017^{1}$.

The current national strategy of tourism development (Ministarstvo turizma, 2013) has identified cruise tourism as one of the key tourism products in Dubrovnik. In 2014 UNESCO has requested that the local government adopts a tourism cruise tourism development strategy (UNESCO, 2015) which was recently presented (Vrtiprah et al., 2017). In the meantime, the local government and Port Authority have introduced measures to limit and redistribute the number of cruise ships calls and to limit the number of daily passengers in the old town. Thus, in 2016, calls have been mostly redistributed between April and October, reaching the peak of 84 calls in September (Lučka uprava Dubrovnik, 2017). The latter reveals the challenge that cruise tourism development and the diverse stakeholders' perceptions of it pose.

1 In the historical centre the ratio is even higher but since the number of tourist staying in the center is not available, it can not be calculated.

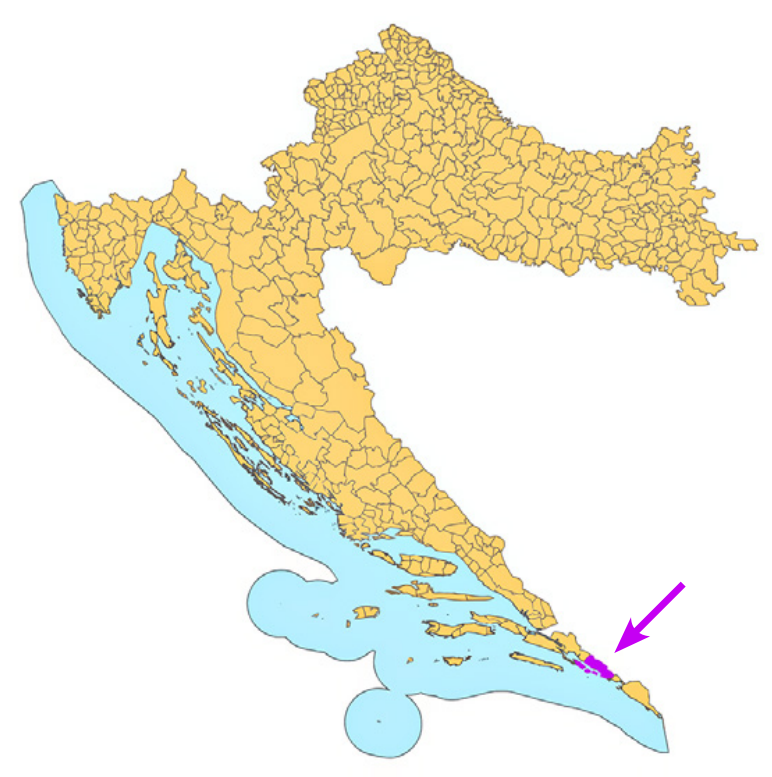

Figure 1. The geographical position of Dubrovnik

Cruise tourism development in Dubrovnik has attracted scholars from different disciplines to explore its environmental impacts (Carić, 2011; Carić \& Mackelworth, 2014; Carić, 2015), implementation of integrated management systems (Raguž et al., 2012), forecasting (Pavlić, I. 2013) and socioeconomic impacts and residents' attitudes (Marušić et al., 2009; Peručić \& Puh, 2012; Lučić et al., 2017; Sindik at al., 2017). However, scholarly studies of other cruise tourism stakeholders in this destination have not been conducted.

\section{Empirical research}

\section{Methodology}

The empirical study was conducted on a sample of leaders in tourism-related government bodies and business organisations using judgmental/purposive sampling (Atkinson \& Flint, 2001; Noy, 2008). The list of 120 participants was compiled based on their competences insight of one co-author, the city vice-major at the time. Before conducting the survey in spring 2013, the respondents were called and informed about the study goals - 105 agreed to participate but specifically and openly requested questionnaire brevity. Thus, a questionnaire was designed in three step process: (1) by literature review of cruise tourism impacts the initial items list was generated, (2) to enhance clarity, relevance and effectiveness key impacts were de- rived through three stakeholder interviews and a four tourism researchers panel and (3) pilot tested on 45 tourism master study students. The final questionnaire encompassed personal data, attitudes towards the cruise tourism impacts, and attitudes towards the suggested measures for cruise tourism future development. The two latter were formulated as 5-point Likert scale questions.

The data analysis conducted with SPSS 22 statistical package, consists of (1) descriptive and (2) quantitative analysis, i.e. non-parametric Mann-Whitney U (M-W $\mathrm{U})$ and Kruskal-Wallis tests (K-W) to analyse the differences of cruise tourism impacts across socio-demographic variables, and exploratory factor analysis (EFA) and Cronbach's Coefficient to assess proposed 
impacts scale's reliability and validity (Carmines \& Zeller, 1979; Gursoy \& Rutherford, 2004).

\section{Research results}

Most of the respondents in this purposive sample were females $(63.8 \%)$, working in the tourism industry (tourism agency 50.5\%, hotel sector $14.3 \%$ ), and unevenly distributed by residence area.

The qualitative analysis results (Table 1) reveal this stakeholder group perceives positive and negative cruise tourism impacts to be moderate (maximum average grade 3.8). The positive impacts are slightly more pronounced, i.e. promotion/image creation, revenues and employment generation score the highest grades $(3.8 ; 3.68 ; 3.36)$. On the other hand, the negative influence on land-based guests' satisfaction (3.67) is perceived to be the most pronounced negative impact of cruise tourism development. The respondents perceive cruise tourism as a generator of conflicts among the guests and the host population (2.89), and its contribution to the crime growth (2.10) to be the least adverse impacts. The vague opinion about impacts (ranging from 12.5 to $35.2 \%$ ) might originate from lack of objective impact studies and the resulitng cacophony of diverse opinions whilst the surprising result that cruise tourism does not increase seasonal prices might be at- tributed to mature development stage of destination and the prestige character/high price level it holds already.

Differences in cruise tourism impacts' perception regarding the respondents' characteristics were tested on three levels (Pranice et al., 2012), namely the effect of independent variables on (1) each of 12 items comprising the cruise impacts scale, (2) positive and negative cruise impacts and (3) all impacts (Table 2). For (2) and (3) step new variables were created by summing up and averaging the cruise impact items for each respondent with prior reverse coding the negative ones.

Research results reveal respondents' sex and workplace are the most important discriminating variables. They influence the respondents' attitude towards most of the positive (except the impact on global promotion and image), and two of seven proposed negative impacts of cruise tourism development (pollution and criminal growth). Additionally, age influences the respondents' perception regarding cruise tourism contribution to the crime growth on land. According to MacNeill and Wozniak (2018), cruise tourism relates to crime and corruption growth in host town, which can be resolved only with adequate policy measures, i.e. increase in government expenditure on policying. Furthermore, place of residence, education and earn-

Table 1. Respondents' perceived cruise tourism impacts

\begin{tabular}{|c|c|c|c|c|c|c|c|c|c|}
\hline \multirow{2}{*}{$\begin{array}{l}\text { Item } \\
\text { code }\end{array}$} & \multirow[t]{2}{*}{ Perceived impacts } & \multicolumn{3}{|c|}{ Strongly disagree* } & \multicolumn{2}{|c|}{ Strongly agree } & \multirow[t]{2}{*}{ Mean } & \multirow[t]{2}{*}{ Mode } & \multirow{2}{*}{$\begin{array}{l}\text { Std. } \\
\text { Dev. }\end{array}$} \\
\hline & & 1 & 2 & 3 & 4 & 5 & & & \\
\hline & \multicolumn{9}{|l|}{ Positive impacts of cruise tourism } \\
\hline 11 & $\begin{array}{l}\text { Strengthens global promotion and image } \\
\text { of the City }\end{array}$ & & 9.5 & 23.8 & 43.8 & 22.9 & 3.80 & 4 & .903 \\
\hline 12 & $\begin{array}{l}\text { Increases the revenues of businesses in the } \\
\text { City }\end{array}$ & 1.0 & 15.2 & 17.1 & 48.6 & 18.1 & 3.68 & 4 & .976 \\
\hline 13 & Increases the employment in the City & 1.9 & 26.7 & 21.9 & 32.4 & 17.1 & 3.36 & 4 & 1.110 \\
\hline 14 & $\begin{array}{l}\text { Fosters the development of other } \\
\text { economic activities in the City }\end{array}$ & 4.8 & 28.6 & 27.6 & 30.5 & 8.6 & 3.10 & 4 & 1.061 \\
\hline \multirow[t]{2}{*}{15} & $\begin{array}{l}\text { Contributes to better valorisation and } \\
\text { protection of cultural heritage of the City }\end{array}$ & 16.2 & 31.4 & 32.4 & 16.2 & 3.8 & 2.60 & 3 & 1.062 \\
\hline & \multicolumn{9}{|l|}{ Negative impacts of cruise tourism } \\
\hline 16 & $\begin{array}{l}\text { Diminishes the land-based tourists' } \\
\text { satisfaction }\end{array}$ & 4.8 & 15.2 & 12.4 & 43.8 & 23.8 & 3.67 & 4 & 1.141 \\
\hline 17 & $\begin{array}{l}\text { Contributes to tourism monoculture } \\
\text { development }\end{array}$ & 2.9 & 18.1 & 29.5 & 39.0 & 10.5 & 3.36 & 4 & .992 \\
\hline 18 & Increases seasonal prices in the City & 6.7 & 22.9 & 22.9 & 36.2 & 11.4 & 3.23 & 4 & 1.129 \\
\hline 19 & Significant pollutant in the City & 10.5 & 15.2 & 35.2 & 25.7 & 13.3 & 3.16 & 3 & 1.161 \\
\hline 110 & $\begin{array}{l}\text { Negative impact on the development of } \\
\text { other forms of tourism }\end{array}$ & 12.4 & 26.7 & 16.2 & 31.4 & 13.3 & 3.07 & 4 & 1.273 \\
\hline 111 & $\begin{array}{l}\text { Contributes to the increase of conflicts } \\
\text { among tourists and hosts }\end{array}$ & 12.4 & 26.7 & 25.7 & 30.5 & 4.8 & 2.89 & 4 & 1.121 \\
\hline 112 & Contributes to the criminal growth & 29.5 & 41.9 & 19.0 & 8.6 & 1.0 & 2.10 & 2 & .956 \\
\hline
\end{tabular}

*in percentage (\%) 
Table 2. Statistical significance of differences in cruise tourism perceptions regarding the respondents' socio-demographic characteristics

\begin{tabular}{|l|c|c|c|c|c|c|}
\hline & Age & Sex & Residence $^{\mathrm{b}}$ & Work place $^{\mathrm{a}}$ & Education $^{\mathrm{a}}$ & Revenues $^{\mathrm{a}}$ \\
\hline $\begin{array}{l}\text { Positive impacts } \\
\text { aggregated }\end{array}$ & .462 & $.000^{*}$ & .563 & $.013^{*}$ & .880 & .564 \\
\hline 11 & .381 & .052 & .095 & .308 & .219 & .802 \\
\hline 12 & .822 & $.007^{*}$ & .697 & $.042^{*}$ & .993 & .750 \\
\hline 13 & .281 & $.000^{*}$ & .853 & $.004^{*}$ & .554 & .498 \\
\hline 14 & .798 & $.002^{*}$ & .526 & $.019^{*}$ & .982 & .506 \\
\hline 15 & .617 & $.000^{*}$ & .818 & $.004^{*}$ & .460 & .594 \\
\hline $\begin{array}{l}\text { Negative impacts } \\
\text { aggregated }\end{array}$ & .367 & .400 & .083 & .266 & .751 & .996 \\
\hline 16 & .473 & .550 & .076 & .149 & .447 & .215 \\
\hline 17 & .406 & .075 & .340 & .160 & .581 & .519 \\
\hline 18 & .743 & .852 & .126 & .233 & .256 & .517 \\
\hline 19 & .270 & $.005^{*}$ & .937 & $.045^{*}$ & .777 & .209 \\
\hline 110 & .757 & .404 & .107 & .204 & .771 & .763 \\
\hline 111 & .219 & .659 & .109 & .122 & .605 & .133 \\
\hline 112 & $.002^{*}$ & $.024^{*}$ & .610 & .163 & .700 & .233 \\
\hline All impacts aggregated & .382 & $.003^{*}$ & .196 & .086 & .690 & .880 \\
\hline
\end{tabular}

${ }^{*} P<0.05 ;^{a}$ Kruskal-Wallis test; ${ }^{b}$ Mann-Whitney $\cup$ test

ing revenues from tourism are not found to be cruise tourism impacts' discriminators.

Regarding the desirable future of cruise tourism development (Table 3), most of the respondents were in favour of its further development; however, they have stressed the need to (1) prolong the tourist stay in a city, (2) to reduce the number of cruise ships, (3) conduct carrying capacity assessment and (4) to prioritise small cruise ships.

\section{Cruise tourism impact scale validity and reliability}

CTIS was assessed using exploratory factor analysis (EFA). First, items measuring negative impacts were reverse coded (Mooi \& Sarstedt, 2011) and the patterned relationship among variables checked in the Correlation matrix. Two items (Seasonal price increase and Tourism monoculture) with a large number of low correlation coefficients were removed (Yong \& Pearce, 2013). With the number of observations exceeding the 1:5 to items ratio, the sample size was appropriate for further analysis (Hair et al. 2014).

Running EFA with remaining 10 items, the Kaiser-Meyer-Olkin measure of sampling adequacy was 0.870 , i.e. meritorious (Mooi \& Sarstedt, 2011) and Bartlett's test of sphericity were significant $\left(\mathrm{X}^{2}=\right.$ $383.750 ; \mathrm{df}=45 ; \mathrm{p}=0.00$ ). The Cattell scree test and the "Eigenvalue" criterion suggested a two-factor solution accounting for 58.22 per cent of variance, which is acceptable (Hair et al., 2014) and somewhat above the average of variance explained found in other studies

Table 3. Respondents' attitudes about future cruise tourism development

\begin{tabular}{|c|c|c|c|c|c|c|c|}
\hline & \multicolumn{3}{|c|}{ Strongly disagree* } & \multicolumn{2}{|c|}{ Strongly agree } & \multirow{2}{*}{ Mean } & \multirow{2}{*}{ Mode } \\
\hline & 1 & 2 & 3 & 4 & 5 & & \\
\hline $\begin{array}{l}\text { The development of "home port" concept in order to prolong } \\
\text { the cruise tourists stay }\end{array}$ & 1.9 & 2.9 & 15.2 & 60 & 20 & 3.93 & 4 \\
\hline $\begin{array}{l}\text { Reducing the cruise ship numbers by introducing daily and } \\
\text { weekly quotas }\end{array}$ & 3.8 & 6.7 & 10.5 & 51.4 & 27.6 & 3.92 & 4 \\
\hline $\begin{array}{l}\text { Carrying capacity assessment in order to optimise the } \\
\text { relationship of land and cruise tourism }\end{array}$ & 1.9 & 1.9 & 20 & 61 & 15.2 & 3.86 & 4 \\
\hline Prioritizing the calls of smaller cruise ships & 3.8 & 15.2 & 21 & 38.1 & 21.9 & 3.59 & 4 \\
\hline Reducing the cruise ship numbers through price policy & 7.6 & 27.6 & 16.2 & 32.4 & 16.2 & 3.22 & 4 \\
\hline $\begin{array}{l}\text { Abandonment of cruise tourism and development of other } \\
\text { forms of tourism }\end{array}$ & 41.9 & 43.8 & 9.5 & 2.9 & 1.9 & 1.79 & 2 \\
\hline
\end{tabular}

*in percentage (\%) 
(Tinsley \& Tinsley, 1987; Peterson, 2000). The factor solutions comply with the rule of at least 3 variables loading on each factor (Hatcher, 1994). Furthermore, solutions goodness of fit was confirmed by non-redundant residuals absolute values and small residuals between the Reproduced and the original Correlation Coefficients Matrix (Mooi \& Sarstedt, 2011; Yong \& Pearce, 2013).

Using a factor loading cut-off of 0.50 , items representing positive cruise tourism impacts loaded on a first factor while the negative impact items loaded on a second (Table 4). Thus, the factors are labelled as such. Cronbach's Alpha coefficient equals 0.819 , and 0.793 for the positive and negative cruise tourism impacts scales, respectively, both above the minimum acceptable guideline of 0.70 for new scales (DeVellis, 2003).
Table 4. Rotated factor loadings for cruise tourism impacts*

\begin{tabular}{|l|c|c|}
\hline & $\begin{array}{c}\text { Positive } \\
\text { impacts }\end{array}$ & $\begin{array}{c}\text { Negative } \\
\text { impacts }\end{array}$ \\
\hline 12 & .814 & \\
\hline 13 & .788 & \\
\hline 14 & .783 & \\
\hline 15 & .630 & \\
\hline 11 & .508 & \\
\hline 110 & & .700 \\
\hline 16 & & .775 \\
\hline 19 & & .566 \\
\hline 111 & & .763 \\
\hline 112 & 29.79 & 28.43 \\
\hline$\%$ variance explained & 29.79 & 58.22 \\
\hline Cummulative variance & 0.819 & 0.793 \\
\hline Cronbach's Alpha & & \\
\hline KMO = 0.870; & & \\
\hline Bartlett's test of sphericity $X^{2}=383.750 ; \mathrm{df}=45 ; \mathrm{P}=0.00 ;$ \\
\hline Varimax Rotation Method & \\
\hline
\end{tabular}

*only contributory variables included in the table

\section{Discussion and conclusion}

This study complements the recent literature by investigating local government and business community attitudes toward cruise tourism development and introducing and validating the CTIS. Compared to residents' attitudes documented in previous studies (average grade from 2.31 to 4.37 in Peručić and Puh, 2012; from 1.49 to 4.68 in Lučić et al., 2017), this stakeholder group has expressed more moderate attitudes towards cruise tourism impacts. Furthermore, the positive impacts are perceived as slightly stronger with promotion/ image creation, revenues and employment generation being the most notable ones. This is in line with residents' studies findings which also put the destination promotion effects, economic benefits (Peručić \& Puh, 2012), and employment generation (Lučić et al., 2017) at the forefront. The most pronounced negative impact is the influence on land-based guests' satisfaction. This reveals that the analysed stakeholders perceive these two forms of tourism to be somewhat conflicted, whilst the previously indicated residents' studies have delivered contradictory results. On the other hand, same as residents (Peručić \& Puh, 2012), these stakeholder groups do not perceive cruise tourism to generate conflicts between guests and the host population.

In this study, sex, workplace, and age are found to be discriminators of cruise tourism impacts, which differs from recent studies proving education, place of residence, and tourism revenues to be discriminators as well (Del Chiappa \& Abbate, 2013; Paulina et al.,
2013; Brida et al., 2012; Peručić \& Puh, 2012; Lučić et al., 2017; Sindik et al., 2017). The non-effect of the place of residence demonstrates that these stakeholders do not exhibit the so-called NIMBY syndrome (Not in my backyard) (Sindik et al., 2017) while the non-effect of tourism revenues shows that the respondents are not dependent on tourism generated income. On the other hand, as in residents'studies (Peručić \& Puh, 2012; Sindik et al., 2017), education was not related to perceived cruise tourism impacts.

The stakeholders support further cruise tourism development and invoke paradigm shift, i.e. homeport development and the carrying capacity assessment to balance the development of cruise and landbased tourism. This is in line with residents' opinion reported in Peručić and Puh (2013) and with desired development direction reported in the first phase of Tourism development strategy (Vrtiprah et al., 2017). The strategy is not yet adopted nor publicly available, so it is yet to be seen if these opinions were built into it. Hopefully they are, considering that assessing stakeholders' perceptions about tourism development and potential future directions are needed to gain or maintain desired tourism development support (Presenza et al., 2013). Moreover, community perceptions of cruise tourism can be used to measure the destination's likelihood of decline (Diedrich \& Garci'aBuades, 2009; Tomljenović et al., 2013), while overall stakeholder' participation in, and attitudes toward 
tourism development are crucial for local "hospitality atmosphere" (Ven, 2015).

The findings of the study provide valuable insights for policy-makers and destination marketers as they confirm the diversity of attitudes toward the cruise tourism development within selected stakeholder groups. Thus, the importance of involving various stakeholders before tourism-related actions are taken is reaffirmed as well as the need to understand and monitor their attitudes towards different types of tourism. In order to increase the stakeholders support, local government and policy-makers should analyse expectations of different stakeholders and conduct adequate persuasive communication activities to deliver tailored messages focusing on the desired balance between the positive and negative tourism impacts (Perdue et al., 1990 as cited in Del Chiappa \& Abbate, 2013). It is crucial, this is done relying on objective measurement of costs and benefits, not only perceptions (Brida et al., 2012b; Paulina et al., 2013). The reasons for this are twofold (Del Chiappa \& Abbate, 2013): (1) residents cannot be expected to be fully aware of impacts of cruise tourism development and they could evaluate these impacts wrongly, (2) the measurement of stakeholders' perceptions should be used as one of several indicators to monitor and assess the tourism sustainability of a destination. To achieve sustainable cruise tourism on the local level, public sector should be able to protect local community and environment and foster its involvement and consultation (MacNeill \& Wozniak, 2018).
Although contributing to a somewhat neglected research area, this study has several limitations, first being the judgmental/purposive sampling. Achieving a representative sample of the selected stakeholder group is a not feasible as its members change and are hard to access. The same goes for their representativeness according to other socio-demographic and discriminatory variables, which are, to the best of the authors' knowledge, not available. Secondly, the study considered only a limited number of factors that discriminate the attitudes toward cruise tourism. Moreover, as the study focuses on a specific destination, the results can not be generalised but are to be considered 'site-specific'. Although where possible, the perceptions were compared to those of residents found in other studies, methodological issues (methods used, years of studies) pose limits to the validity of those comparisons. Final limitation is CTIS not being tested on second sample and confirmed by confirmatory factor analysis. However, as the main research goal was an insight into perceptions of a rather neglected but influental stakeholder group, the procedure deems acceptable.

Considering the conducted research and its limitations, the authors would advise any future research to: (1) explore the interrelation between destinations characteristics, i.e. stage of tourism development, seasonality etc. and stakeholders' cruise tourism impacts perception; (2) to conduct longitudinal studies; and (3) to include other respondent specific variables discriminating attitudes towards cruise tourism development.

\section{References}

Ali, F., Hussain, K., Nair, V., \& Kumar, N.P. (2017). Stakeholders' perceptions and attitudes towards tourism development in a mature destination. Tourism, 65(2), 173.

Alonso, A.D., \& Alexander, N. (2017). Stakeholders' perceived gains and obstacles of cruise ship tourism development: the case of La Palma Island. In R. Dowling \& C. Weeden (Eds.), Cruise ship tourism. (pp. 363-377). Wallingford: CABI Publishing. doi:10.1079/9781780646084.0363

Atkinson, R., \& Flint, J. (2001). Accessing hidden and hard-to-reach populations: Snowball research strategies. Social research update, 33(1), 1-4.

Bimonte, S., \& Punzo, L.F. (2007). The evolutionary game between tourist and resident populations and Tourist Carrying Capacity. International Journal of Technology and Globalisation, 3(1), 73. doi:10.1504/ ijtg.2007.012361

Brida, J.G., Riaño, E., \& Aguirre, S.Z. (2011). Residents' attitudes and perceptions towards cruise tourism development: A case study of Cartagena de Indias (Colombia). Tourism and Hospitality Research, 11(3), 181-196. doi:10.1177/1467358411415153

Brida, J.G., Del, C.G., Meleddu, M., \& Pulina, M. (2012). Cruise Tourism Externalities and Residents' Support: A Mixed Approach. Economics: The OpenAccess, Open-Assessment E-Journal, 6(2012-40), 1. doi:10.5018/economics-ejournal.ja.2012-40

Brida, J.G., Chiappa, G.D., Meleddu, M., \& Pulina, M. (2012). The perceptions of an island community towards cruise tourism: A factor analysis. Tourism, 30(1), 29-42.

Carić, H. (2011). Cruising Tourism Environmental Impacts: Case Study of Dubrovnik, Croatia. Journal of Coastal Research, 61, 104-113. doi:10.2112/si61001.2

Carić, H. (2016). Challenges and prospects of valuation - cruise ship pollution case. Journal of Cleaner Production, 111, 487-498. doi:10.1016/j. jclepro.2015.01.033 
Carić, H., \& Mackelworth, P. (2014). Cruise tourism environmental impacts - The perspective from the Adriatic Sea. Ocean \& Coastal Management, 102, 350-363. doi:10.1016/j.ocecoaman.2014.09.008

Carmines, E., \& Zeller, R. (1979). Reliability and Validity Assessment. Thousand Oaks California, USA: SAGE Publications. doi:10.4135/9781412985642

Castillo-Manzano, J.I., Fageda, X., \& Gonzalez-Laxe, F. (2014). An analysis of the determinants of cruise traffic: An empirical application to the Spanish port system. Transportation Research Part E: Logistics and Transportation Review, 66, 115-125. doi:10.1016/j. tre.2014.03.008

Castillo-Manzano, J.I., Lopez-Valpuesta, L., \& Alanís, F.J. (2015). Tourism managers' view of the economic impact of cruise traffic: the case of southern Spain. Current Issues in Tourism, 18(7), 701-705. doi :10.1080/13683500.2014.907776

Državni zavod za statistiku. (2011). Popis stanovništva. Available at: https://www.dzs.hr/hrv/censuses/census2011/results/htm/Ho1_01_03/ho1_01_03_zup19. html.

d'Angella Francesca, , \& Go, F.M. (2009). Tale of two cities' collaborative tourism marketing: Towards a theory of destination stakeholder assessment. Tourism Management, 30(3), 429-440. doi:10.1016/j.tourman.2008.07.012

Del, C.G. (2015). Community integration: a case study of Costa Smeralda. In E. Fayos-solà, J. Silva, \& J. Jafari (Eds.), Knowledge management in tourism: Policy and governance applications bridging tourism theory and practice. (pp. 243-263). Emerald. doi:10.1108/s2042-1443(2012)0000004016

Del, C.G., \& Abbate, T. (2016). Island cruise tourism development: a resident's perspective in the context of Italy. Current Issues in Tourism, 19(13), 1372-1385. doi:10.1080/13683500.2013.854751

Del, C.G., Lorenzo-Romero, C., \& Gallarza, M. (2018). Host community perceptions of cruise tourism in a homeport: A cluster analysis. Journal of Destination Marketing \& Management, 7, 170-181. doi:10.1016/j. jdmm.2016.08.011

Devellis, R.F. (2003). Scale Development (2nd ed.). Thousand Oaks, CA: Sage Publications.

Diedrich, A., \& García-Buades, E. (2009). Local perceptions of tourism as indicators of destination decline. Tourism Management, 30(4), 512-521. doi:10.1016/j.tourman.2008.10.009

Fredline, E., \& Faulkner, B. (2000). Host community reactions: A cluster analysis. Annals of Tourism Research, 27(3), 763-784. doi:10.1016/so16o7383(99)00103-6

Freeman, R.E. (1984). Strategic Management: A Stakeholder Approach. Boston: Pitman.
Gursoy, D., \& Rutherford, D.G. (2004). Host attitude toward tourism: an improved structural model. Annals of Tourism Research, 31(3), 495-516. doi:10.1016/j. annals.2003.08.008

Hair, J.F., Black, J.W.C., Babin, B.J., \& Anderson, R.E. (2014). Multivariate data analysis (7th Edition). Harlow: Pearson Education Limited.

Hatcher, L. (1994). A Step-By-Step Approach to Using the SAS Systems for Factor Analysis and Structural Equation Modeling, Cary. SAS Institute.

Jordan, E.J., \& Vogt, C.A. (2017). Residents' Perceptions of Stress Related to Cruise Tourism Development. Tourism Planning \& Development, 14(4), 527547. doi:10.1080/21568316.2017.1287123

Kuvan, Y., \& Akan, P. (2012). Conflict and agreement in stakeholder attitudes: residents' and hotel managers' views of tourism impacts and forest-related tourism development. Journal of Sustainable Tourism, 20(4), 571-584. doi:10.1080/o9669582.2011.61782 4

Lee, T.H., \& Jan, F.H. (2019). Can community-based tourism contribute to sustainable development? Evidence from residents' perceptions of the sustainability. Tourism Management, 70, 368-380. doi:10.1016/j.tourman.2018.09.003

Lester, J., \& Weeden, C. (2004). Stakeholders, the natural environment and the future of Caribbean cruise tourism. International Journal of Tourism Research, 6(1), 39-50. doi:10.1002/jtr.471

London, W.R., \& Lohmann, G. (2014). Power in the context of cruise destination stakeholders' interrelationships. Research in Transportation Business \& Management, 13, 24-35. doi:10.1016/j. rtbm.2014.11.004

Lučić, I., Sindik, J., \& Manojlović, N. (2017). How do Dubrovnik Inhabitants Perceive the Cruise Tourism?. Naše more, 64(2), 54-6o. doi:10.17818/ $\mathrm{nm} / 2017 / 2.10$

Lučka uprava Dubrovnik. (2017). Kružna putovanja statistika [Cruise tourism - statistics]. Available at: http://portdubrovnik.hr/statistika/.

MacNeill, T., \& Wozniak, D. (2018). The economic, social, and environmental impacts of cruise tourism. Tourism Management, 66, 387-404. doi:10.1016/j.tourman.2017.11.002

Marušić, Z., Horak, S., \& Tomljenović, R. (2008). The Socioeconomic Impacts of Cruise Tourism: A Case Study of Croatian Destinations. Tourism in Marine Environments, 5(2), 131-144. doi:10.3727/154427308787716767

McCaughey, R., Mao, I., \& Dowling, R. (2018). Residents' perceptions towards cruise tourism development: the case of Esperance, Western Australia.. Tourism Recreation Research, 43(3), 403-408. do i:10.1080/02508281.2018.1464098 
Ministarstvo turizma Republike Hrvatske. (2013). Strategija razvoja turizma Republike Hrvatske do 2020. godine/The national strategy of tourism development till 2020. Available at: https://narodne-novine.nn.hr/clanci/sluzbeni/2013_05_55_1119.html.

Mooi, E., \& Sarstedt, M. (2011). A Concise Guide to Market Research: The process, data and methods using IBM SPSS Statistics. Belin-Heidelberg: Springer-Verlag.

Noy, C. (2008). Sampling Knowledge: The Hermeneutics of Snowball Sampling in Qualitative Research. International Journal of Social Research Methodology, 11(4), 327-344. doi:10.1080/13645570701401305

Nunkoo, R., \& Gursoy, D. (2012). Residents' support for tourism: An identity perspective. Annals of Tourism Research, 39(1), 243-268. doi:10.1016/j.annals.2011.05.006

Pulina, M., Meleddu, M., \& Del, C.G. (2013). Residents' choice probability and tourism development. Tourism Management Perspectives, 5, 57-67. doi:10.1016/j. tmp.2012.10.003

Pavlić, I. (2013). Cruise tourism demand forecastingthe case of Dubrovnik. Tourism and Hospitality Management, 19(1), 125-142.

Peručić, D., \& Puh, B. (2012). Attitudes of citizens of Dubrovnik towards the impact of cruise tourism on Dubrovnik. Tourism and Hospitality Management, 18(2), 213-228.

Peterson, R.A. (2000). A Meta-Analysis of Variance Accounted for and Factor Loadings in Exploratory Factor Analysis. Marketing Letters, 11(3), 261-275. doi:10.1023/a:1008191211004

Petrić, L., \& Pivčević, S. (2016). Community based tourism development - insights from Split, Croatia. In Tourism and hospitality industry 2016 - trends and challenges, Proceedings of International Congress, Opatija, Croatia. (pp. 294-307).

Pranić, L., Petrić, L., \& Cetinić, L. (2012). Host population perceptions of the social impacts of sport tourism events in transition countries: Evidence from Croatia. International Journal of Event and Festival Management, 3(3), 236-256. doi:10.1108/17582951211262684

Presenza, A., Del, C.G., \& Sheehan, L. (2013). Residents' engagement and local tourism governance in maturing beach destinations. Evidence from an Italian case study. Journal of Destination Marketing \& Management, 2(1), 22-30. doi:10.1016/j. jdmm.2013.01.001

Raguž, I.V., Peručić, D., \& Pavlić, I. (2012). Organization and implementation of integrated management system processes: Cruise port Dubrovnik. International review of Management and Marketing, 2(4), 199-209.
Sdrali, D., Goussia-Rizou, M., \& Kiourtidou, P. (2015). Residents' perception of tourism development as a vital step for participatory tourism plan: a research in a Greek protected area. Environment, Development and Sustainability, 17(4), 923-939. doi:10.1007/ s10668-014-9573-2

Sharpley, R. (2008). Tourism, tourists and society [4th ed.]. Huntingdon: Elm Publications.

Sharpley, R. (2014). Host perceptions of tourism: A review of the research. Tourism Management, 42, 3749. doi:10.1016/j.tourman.2013.10.007

Shone, M.C., Wilson, J., Simmons, D.G., \& Stewart, E.J. (2017). Sailing into stormy waters? Understanding the community impacts of cruise tourism growth in Akaroa, New Zealand. In R. Dowling \& C. Weeden (Eds.), Cruise ship tourism. (pp. 393-407). Wallingford: CABI Publishing. doi:10.1079/9781780646084.0393

Sindik, J., Manojlović, N., \& Klarić, M. (2017). Percipirani učinci kruzing turizma kod stanovnika Dubrovnika [Percived cruise tourism impacts of Dubrovnik inhabitants]. Ekonomska misao i praksa, 151-170.

Telfer, D., \& Sharpley, R. (2008). Tourism and development in the developing world. Abingdon: Routledge.

Timur, S., \& Getz, D. (2008). A network perspective on managing stakeholders for sustainable urban tourism. International Journal of Contemporary Hospitality Management, 20(4), 445-461. doi:10.1108/09596110810873543

Tinsley, H.E., \& Tinsley, D.J. (1987). Uses of factor analysis in counseling psychology research. Journal of Counseling Psychology, 34(4), 414-424. doi:10.1037//0022-0167.34.4.414

Todd, L., Leask, A., \& Ensor, J. (2017). Understanding primary stakeholders' multiple roles in hallmark event. Tourism Management, 59, 494-509. doi:10.1016/j.tourman.2016.09.010

Tomljenović, R., Boranić, Ž.S., \& Marušić, Z. (2013). Stakeholder Support for Tourism Development. Acta Turistica, 25(1), 73-102.

UNESCO. (2015). Report on the UNESCO ICOMOS reactive monitoring mission to old city of Dubrovnik, Croatia from 27th October to 1st November. Croatia. Available at: whc.unesco.org/document/141053.

Uran, M.M., \& Zirdum, Ž. (2017). Assessing impact of cruising tourism in Slovenia. Pomorstvo, 31(1), 27-32. doi:10.31217/p.31.1.5

Ven, S. (2015). Residents' participation, perceived impacts, and support for community-based ecotourism in Cambodia: A latent profile analysis. Asia Pacify c Journal of Tourism Research, DOI: 10.1080/10941665.2015.1075565..

Vrtiprah, V., Ban, I., Pavlić, I., Raguž, V.I., Mihajlović, I., Portolan, A., .. . Račić, M. (2017). Strategija razvoja turizma i odredbe o kruzing turizmu na području 
grada - Dubrovnika - I faza [Tourism development strategy and cruise tourism development directions in Dubrovnik town area - I phase]. Dubrovnik.

Weeden, C., Lester, J., \& Thyne, M. (2011). Cruise Tourism: Emerging Issues and Implications for a $\mathrm{Ma}-$ turing Industry. Journal of Hospitality and Tourism Management, 18(1), 26-29. doi:10.1375/jhtm.18.1.26

Woosnam, K.M., Draper, J., Jiang, J.K., Aleshinloye, D.K., \& Erul, E. (2018). Applying self-perception theory to explain residents' attitudes about tourism development through travel histories. Tourism Management, 64, 357-368. doi:10.1016/j.tourman.2017.09.015

Yong, A.G., \& Pearce, S. (2013). A Beginner's Guide to Factor Analysis: Focusing on Exploratory Factor Analysis. Tutorials in Quantitative Methods for Psychology, 9(2), 79-94. doi:10.20982/ tqmp.09.2.p079 